\title{
ANALISIS FAKTOR - FAKTOR YANG MEMPENGARUHI PENDAPATAN ANGGOTA KELOMPOK SADAR WISATA PADA USAHA INDUSTRI KECIL KERAJINAN SOUVENIR DI KOTA MATARAM
}

\section{Analysis of Factors that Influence the Income of the Community members in the 'Sadar Wisata' Group on the Small Industries of Souvenirs in Mataram}

\author{
Edi Irawan ${ }^{1}$ \\ ${ }^{1}$ Program Studi Ekonomi Pembangunan, Fakultas Ekonomi Dan Bisnis Universitas Teknologi Sumbawa \\ e-mail: edihaidah@gmail.com
}

\begin{abstract}
This objective of this study is to analyze the factors that influence the income of the community members in the group of 'Sadar Wisata' on the small industries of souvenirs in Mataram. The dependent variable in this study is the income of the group 'Sadar Wisata' members, while the independent variables are the self owned capital, external capital sources, and the length of the business. This study is supported by primary data and secondary data. The source of primary data was 59 people as the samples. Data were analyzed using the multivariable linear regression analysis. The results of the study show that all independent variables simultaneously have a significant impact on the dependent variable. Meanwhile, self owned capital variable, partially has a positive and significant impact on the income of the 'Sadar Wisata' group members. On the other hand, external capital sources variable has unsignificant impact on the income of the group members.in addition, a positive and significant impact on the income of the group members is also caused by the length of business variable.
\end{abstract}

Key words: self owned capital factor, external sources of capital factor, length of business factor, income of the group members

\section{ABSTRAK}

Tujuan penelitian ini adalah untuk menganalisis faktor - faktor yang mempengaruhi pendapatan anggota kelompok sadar wisata pada usaha industri kecil kerajinan souvenir di Kota Mataram. Variabel yang digunakan variabel terikat yaitu pendapatan anggota kelompok sadar wisata dan variabel bebas yaitu modal sendiri, modal diluar modal sendiri dan lama berusaha. Penelitian ini menggunakan data primer serta data skunder sebagai pendukung. Untuk data primer, sampel yang digunakan berjumlah 59 orang. Data dianalisis menggunkan analisis regresi liner berganda. Hasil penelitian(pengolahan data pada taraf $\alpha=5 \%$ ) menunjukkan bahwa hasil pengujian secara serentak tingkat modal sendiri,modal diluar modal sendiri dan lama berusaha berpengaruh signifikan terhadap pendapatan anggota kelompok sadar wisata pada usaha industri kerajinan kecil souvenir di Kota Mataram. Secara parsial variabel modal sendiri mempunyai pengaruh positif dan signifikan terhadap pendapatan anggota kelompok sadar wisata,variabel modal diluar modal sendiri mempunyai pengaruh tidak signifikan terhadap pendapatan anggota kelompok sadar wisata dan variabel lama berusaha mempunyai pengaruh yang positif dan signifikan terhadap pendapatan anggota kelompok sadar wisata.

Kata Kunci: Modal sendiri, modal diluar modal sendiri danLama berusaha

\section{Pendahuluan}

Salah satu sasaran yang hendak dicapai dalam pembangunan nasional adalah suatu pertumbuhan ekonomi yang dapat mempercepat peningkatan pendapatan dan kesempatan kerja. Hal ini berarti bahwa pembangunan ekonomi diarahkan pada pendayagunaan sumber daya alam dan sumber daya manusia seefisien dan seefektif mungkin sehingga menghasilkan produksi yang dapat meningkatkan kesejahteraan masyarakat. Pembangunan adalah suatu proses multidimensional yang meliputi perubahan dasar atas struktur sosial dan sikap masyarakat serta institusi-institusi nasional disamping tetap mengejar percepatan pertumbuhan ekonomi, mengatasi kesenjangan pendapatan dan hasil-hasil pembangunan serta mengurangi kasus kemiskinan (Todaro, 2014:17). 
Proses pembangunan seringkali dikaitkan dengan proses industrialisasi. Proses industrialisasi dan pembangunan industri sebenarnya merupakan satu jalur kegiatan untuk meningkatkan kesejahteraan rakyat dalam arti tingkat hidup yang lebih maju maupun taraf hidup yang lebih bermutu. Menurut Arsyad ( 1997 ;68) Pembangunan industri merupakan suatu fungsi dari tujuan pokok kesejahteraan rakyat, bukan merupakan kegiatan yang mandiri untuk hanya sekedar mencapai fisik saja.

Sektor industri diyakini sebagai sektor yang dapat memimpin sektor-sektor lain dalam sebuah perekonomian menuju kemajuan. Dalam bukunya yang di tulis oleh Dumairy (Dumairy, 1996; 125) Produk-produk industrial selalu memiliki "dasar tukar" (term of trade) yang tinggi atau lebih menguntungkan serta menciptakan nilai tambah yang besar dibanding produk-produk sektor lain.

Menurut Undang-undang No. 9 Tahun 1995 tentang perindustrian oleh Departemen Perindustrian, industri adalah suatu kegiatan ekonomi yang mengolah bahan mentah, bahan baku, barang setengah jadi dan barang jadi, dan menggunakan teknologi sederhana misalnya: industri kerajinan, industri alat-alat rumah tangga dan perabotan dari tanah (Handoko,2002). Sektor industri merupakan prioritas utama pembangunan ekonomi tanpa mengabaikan pembangunan di sektor lain. Sektor industri dibedakan menjadi industri formal dan industri non formal. Adapun jumlah industri formal dan non formal awal dapat dilihat pada tabel 1.1 sebagai berikut:

Tabel 1. Jumlah Industri formal dan non formal di Kota Mataram Tahun 2009 - 2013

\begin{tabular}{ccccc}
\hline Tahun & $\begin{array}{c}\text { Industri Formal Dan } \\
\text { Industri Non formal } \\
\text { (unit) }\end{array}$ & $\mathbf{\%}$ & $\begin{array}{c}\text { Jumlah Tenaga Kerja } \\
\text { Yang terserap } \\
\text { (orang) }\end{array}$ & $\%$ \\
\hline 2010 & 2.915 & 24 & 15.920 & 23 \\
2011 & 3.103 & 26 & 17.141 & 24 \\
2012 & 2.686 & 22 & 17.851 & 26 \\
2013 & 3.517 & 28 & 18.869 & 27 \\
2010 & 2.915 & 24 & 15.920 & 23 \\
\hline
\end{tabular}

Sumber: BPS Kota Mataram 2014

Dari tabel 1 diatas dijelaskan bahwa Industri formal dan non formal di Mataram pada tahun 2013 tercatat sebesar 3.517 unit perusahan atau $28 \%$. Dengan jumlah penyerapan tenaga kerja sebanyak 18.869 orang atau $27 \%$. Jika dibandingkan dengan tahun 2012, jumlah perusahaan dan tenaga kerja industri formal dan non formal di Mataram pada tahun 2013 mengalami peningkatan sebesar 831 perusahaan dan 1.018 orang tenaga kerja. Hal ini menunjukkan bahwa peran aktif baik dari industri formal dan non formal dapat mempengaruhi laju pergerakan dari penyerapan tenaga kerja yang ada di Kota Mataram. Untuk itu industri yang bersifat formal dan non formal dapat mempengaruhi penyerapan tenaga kerja dan pada akhirnya akan mempengaruhi tingkat pendapatan di masyarakat Kota Mataram, salah satu industri formal yang dapat mendorong peningkatan pendapatan di Kota Mataram adalah pengolahan usaha di industri kerajinan kecil.
Menurut Departemen Perdagangan (2009) industri kerajinan kecil adalah kegiatan kreatif yang berkaitan dengan kreasi, produksi dan distribusi produk yang dibuat dan dihasilkan oleh tenaga pengrajin, berawal dari proses desain sampai dengan proses penyelesaian produknya, meliputi barang kerajinan yang terbuat dari batu berharga, serat alam maupun buatan, kulit, rotan, bambu, kayu, logam (emas, perak, tembaga, perunggu, besi) kayu, kaca, porselin, kain, marmer, tanah liat dan kapur.

Usaha pada industri kecil dirasakan lebih ringan dan sederhana oleh karena itu biasanya pekerjanya dari lingkungan keluarga. sehingga prosedur hukumnya masih sederhana. Industri kecil mudah dalam proses pendiriannya demikian juga mudah untuk dibubarkan tanpa harus melalui prosedur yang rumit karena tidak menyangkut orang lain, jadi kapanpun dapat dibubarkan jika dikehendaki (Subanar, 1995;201-21). 
Menurut Irsan A. Saleh (1986) bahwa terdapat beberapa alasan kuat yang mendasari keberadaan industri kecil dalam perekonomian Indonesia. Alasan yaitu

1. Sebagian besar populasi industri kecil berlokasi di pedesaan, sehingga jika dikaitkan dengan semakin meningkatnya tenaga kerja dan merupakan salah satu pemecahan maslah tenaga kerja.

2. Beberapa jenis kegiatan industri kecil banyak menggunakan bahan baku dari sumber-sumber lingkungan terdekat dari lokasi industri tersebut yang menyebabkan biaya industri ditekan rendah sehingga dapat mengurangi pemborosan biaya produksi.

3. Tetap adanya permintaan terhadap beberapa jenis komoditi yang diproduksi secara masal.

Untuk itu industri kecil perlu dibina dan dikembangkan dengan baik sehingga dapat memperbesar sumbangannya bagi perekonomian daerah pada umumnya dan memberikan sumbangan bagi pengusaha industri kecil itu sendiri.. Oleh sebab itu dibutuhkan komitmen yang lebih besar dari pemerintah terhadap upaya peningkatan industri kecil dan menengah dalam perekonomian masyarakat melalui pembinaan yang mencakup permodalan seperti kredit untuk usaha kecil dan menengah, bantuan teknologi dan informasi, pengembangan sumber daya manusia dan pemasarannya.

Wujud dari industri yang kuat dan maju memiliki ciri antara lain adalah industri yang berdaya saing tinggi dan bertumpu pada sumber daya manusia, industri yang berkualitas dan kemampuan penguasaan teknologi yang tinggi sehingga mampu menghasilkan produk unggulan yang bernilai. Industri kecil yang berkembang semakin handal sebagai tulang punggung pembangunan industri terutama sebagai pemasok dan penopang industri unggulan.

Sampai saat ini yang menjadi salah satu masalah yang dihadapi dalam mengembangkan industri kecil yaitu modal sendiri yang dimiliki oleh pengusaha pengrajin industri masih kurang untuk bisa menopang usahanya, maka dari pada itu diperlukan faktor pendukung diluar modal sendiri seperti modal bantuan dari pemerintah dan pinjaman dari pihak bank. Adapun bantuan dari pemerintah daerah masih memiliki beberapa kekurangannya seperti bantuan yang belum merata jumlahnya dan kendala prosedur penerimaan bantuan modal. Kemudian faktor lain dari modal diluar modal sendiri dari pinajaman pihak bank adalah adanya bunga yang tinggi dibebankan kepada pengarajin sehingga dapat berdampak pada perolehan pendapatan. Oleh sebab tersebut baik modal sendiri maupun modal diluar modal sendiri yang dimiliki oleh pengrajin haruslah bisa menopang dari usah tersebut. Sehingga dengan faktor modal yang kuat diharapkan dapat juga memperlancar arus perekonomian khususnya di Kota Mataram. Salah satu industri kecil yang dapat mendorong pertumbuhan ekonomi mempercepat peningkatan pendapatan serta kesempatan kerja adalah usaha industri kerajinan kecil souvenir.

Usaha industri kecil kerajinan souvenir dalam penelitian ini adalah yang dilakukan oleh masyarakat Kota Mataram yang tergabung dalam anggota kelompok sadar wisata. Salah satu kegiatan yang dilakukan oleh anggota kelompok sadar wisata adalah usah ketrampilan dibidang industri kecil kerajinan souvenir. Adapun anggota yang terlibat di dalamnya ada yang baru terjun di dunia usaha industri kecil kerajinan souvenir dan ada juga yang sudah lama. Dari kegiatan usaha yang dijalani oleh anggota kelompok sadar wisata ada beberapa produk unggulan yang dihasilkan seperti cincin dan gelang, kalung,pin, gantungan kunci,gelas hias dan piring hias. Dari hasil produk yang dihasilkan tersebut yang perlu dikembangkan adalah proses pengelolaannya, mulai dari modal yang dimiliki, pemberdayaan sumber manusia sampai pada tingkat pemasaran baik di dalam daerah maupun di luar daerah.

Terkait dengan hal diatas untuk menunjang peningkatkan pengembangan usaha industri kerajinan kecil, pada tahun 2011 pemerintah Provinsi Nusa Tenggara Barat khususnya di kota Mataram membentuk anggota kelompok sadar wisata dan melaksanakan pemberdayaan pengembangan usaha pada anggota kelompok sadar wisata di kota mataram. Kegiatan ini dimaksudkan untuk Meningkatkan kemampuan dan keterampilan pada anggota dalam mengelola bidang usaha industri kerajinan kecil, dengan harapan dapat meningkatkan pendapatan. Maka dari itu pemerintah ikut secara aktif untuk membantu kegiatan tersebut melalui pemberian bantuan modal usaha dan penyuluhan ketrampilan usaha. 
Mengingat peranan penting usaha industri kerajinan kecil souvenir di Kota Mataram dalam menciptakan dan meningkatkan pendapatan, strategi pembangunan industri sebaiknya memasukkan bantuan pada sektor ini untuk mengatasi masalah- masalahnya, seperti produktivitas yang rendah, pengendalian mutu dan lain-lain, perlu dipahami bahwa tujuan akhir dari usaha ini adalah meningkatkan kesejahteraan masyarakat kalangan bawah dan masyarakat luas pada umumnya. Perkembangan jumlah usaha industri kecil dan penyerapan tenaga kerja di Kota Mataram dapat dilihat pada tabel sebagai berikut:

Tabel 2. Jumlah Industri Kecil dan Tenaga Kerja di Kota Mataram Tahun 2009 - 2013

\begin{tabular}{lcccc}
\hline Tahun & $\begin{array}{c}\text { Jumlah Usaha } \\
\text { Industri Kecil }\end{array}$ & $\begin{array}{c}\text { Prosentase } \\
\mathbf{( \% )}\end{array}$ & $\begin{array}{c}\text { Jumlah tenaga kerja } \\
\text { yang terserap (org) }\end{array}$ & $\begin{array}{c}\text { Prosentase } \\
\text { (\%) }\end{array}$ \\
\hline 2009 & 4,054 & 24 & 16,925 & 19 \\
2010 & 4,249 & 25 & 19,424 & 22 \\
2011 & 2,915 & 16 & 15,920 & 18 \\
2012 & 3,103 & 17 & 17,141 & 20 \\
2013 & 3,285 & 18 & 17,851 & 21 \\
jumlah & 17,606 & 100 & 87,261 & 100 \\
\hline
\end{tabular}

Sumber: BPS Kota Mataram, 2014

Dari tabel 2 diketahui bahwa jumlah industri kecil dan penyerapan tenaga kerja, dalam kurun waktu 5 tahun cenderung fluktiatif. Hal ini ditunjukkan pada 2012 dan 2013, dimana pada tahun 2013 mengalami peningkatan yang cukup signifikan dengan jumlah usaha industri kecil sebanyak 3,285 unit atau $18 \%$, dengan jumlah tenaga kerja sebanyak 17,851 orang atau $21 \%$ dengan mengalami peningkatan dari tahun sebelumnya sebanyak 182 unit usaha dengan diikuti perubahan peningkatan penyerapan tenaga kerja sebanyak 710 orang. Hal ini menunjukkan bahwa industri kerajinan kecil mempunyai prospek yang lebih baik untuk dikembangkan sebagai salah satu alternatif industri yang mampu menanggulangi masalah pendapatan.

Data yang bersumber dari dinas kebudayaan dan pariwisata Provinsi Nusa Tenggara Barat Kelompok sadar wisata di kota Mataram terdapat di empat kecamatan yaitu Kecamatan Ampenan ( Bintaro indah, Ampenan bahari I,Ampenan bahari II, Banjar indah), Kecamatan Sekarbela ( Bajang maju,Amanda,Bajang kano) ,Kecamatan Cakranegara ( Melati,Gelombnag cinta, Rasa sayang) dan Kecamatan Mataram ( Beriuq maju, Mekar sari, Kenanga, Mawar merah ) yang terdiri dari 144 anggota. Adapun hasil industri kecil kerajinan souvenir yang dihasilkan oleh kelompok sadar wisata di empat kecamatan berupa gantungan kunci, gelas hias, piring hias, pin,kalung dari mutiara air laut dan air tawar,gelang dan cincin dari mutiara air laut dan air tawar.

Produk souvenir yang dihasilkan oleh anggota kelompok sadar wisata pada dasarnya sama dengan produk yang dihasilkan oleh usaha kerajinan lainnya,hanya saja yang menjadi perbedaannya adalah kegiatan yang dilakukan oleh anggota kelompok sadar wisata ditopang dari segi bantuan pemerintah daerah baik berupa bantuan materi dan non materi. Bantuan berupa materi seperti uang dan bantuan non materi seperti memberikan bantuan tenaga ahli penyuluhan dan bantuan promosi baik di dalam daerah maupun diluar daerah. Sehingga dapat mempermudah mempercepat peningkatan pendapatan anggota kelompok sadar wisata.

Usaha yang dijalani oleh anggota kelompok sadar wisata, pada dasarnya telah mereka jalani sebelum mereka masuk jadi anggota kelompok sadar wisata. Adapaun tujuan mereka masuk di dalam anggota kelompok sadar wisata adalah agar dapat memperoleh akses jaringan yang kuat dari adanya dukungan pemerintah daerah sehingga dapat membantu peningkatan usaha kerajinan souvenir dan dari pemerintah merasa terbantu juga dengan adanya pengalaman lama usaha mereka karena skill dasar telah dibentuk sebelumnya tinggal dikembangkan ke 
depannya. Sehingga diharapkan produk yang dihasilkan dapat menghasilkan produk yang bermutu tinggi.

Tetapi di sisi lain demi mencapai tujuan membantu dan mensukseskan peningkatan pendapatan anggota kelompok sadar wisata dalam usaha industri kerajinan kecil souvenir, maka diperlukan modal yang kuat. Modal yang dimaksudkan di sini adalah modal untuk modal produksi. Adapun sumber modal yang didapatkan kelompok sadar wisata berasal modal sendiri dan modal diluar modal sendiri seperti modal bantuan dari pemerintah dan modal pinjaman. Modal bantuan diperoleh dari pemerintah daerah dan dari pihak perbankan. Beberapa anggota kelompok sadar wisata memberikan saran untuk penambahan bantuan modal diharapkan dapat meningkat tiap tahunnya demi kelancaran usaha industri kerajinan souvenir. Kemudian dengan sumber dana yang kuat maka diharapkan tingkat pendapatan yang diperoleh oleh anggota kelompok sadar wisata dapat meningkat dan tingkat produktivitas dan pada akhirnya dapat meningkatkan pendapatan.

Keterlibatan secara aktif dan berkelanjutan dari pihak - pihak yang terkait seperti pihak pemerintah dan pihak swasta dalam menunjang keberhasilan dari usaha industri kerajinan kecil souvenir yang dilakukan oleh anggota kelompok sadar wisata di kota Mataram diharapkan dapat mendorong peningkatkan pendapatan.

Mengingat pentingnya usaha industri kerajinan kecil souvenir dalam meningkatkan pendapatan anggota kelompok sadar wisata di kota Mataram maka masih perlu mendapatkan perhatian serius dari pemerintah dan pihak swasta terkait terutama dalam bantuan modal usaha sehingga diharapkan dapat menambah tingkat poduktivitas dan pada akhirnya akan meningkatkan pendapatan.

Terkait dari uraian diatas, penulis mengadakan penelitian terhadap usaha industri kerajinan kecil souvenir terkait dengan faktor - faktor yang mempengaruhi pendapatan anggota kelompok sadar wisata di kota Mataram,. Dalam penelitian ini dibatasi pada input modal sendiri, modal diluar modal sendiri dan lama berusaha yang dapat membantu meningkatkan pendapatan anggota kelompok sadar wisata.

\section{Metode Penelitian}

Jenis penelitian yang digunakan dalam penelitian ini adalah penelitian diskriptif yaitu suatu penelitian yang membuat diskripsi mengenai situasi-situasi atau kejadiankejadian. Tujuan penelitian diskriptif adalah untuk menggambarkan atau memecahkan masalah secara sistematis, faktual, dan akurat mengenai fakta-fakta dan sifat-sifat populasi atau daerah tertentu. Sebagian ahli memberikan arti penelitian diskriptif itu lebih luas dan mencakup segala macam bentuk penelitian kecuali penelitian historis dan penelitian eksperimental. (Rianse, 2008; 30).

Metode diskriptif adalah suatu metode dalam meneliti status kelompok manusia, studi obyek, suatu kondisi, suatu sistem pemikiran ataupun suatu kelas peristiwa pada masa sekarang. Tujuan penelitian diskriptif ini adalah untuk membuat diskripsi, gambaran atau lukisan secara sistematis, faktual dan akurat mengenai fakta-fakta, sifat-sifat serta hubungan antar fenomena yang diselidiki (Nazir, 1998; 63).

Populasi yang dipilih dalam penenelitian ini adalah seluruh anggota kelompok sadar wisata di kota Mataram yang tersebar di 4 kecamatan terdiri 144 orang (Depudpar, 2012).

Untuk menentukan ukuran sampel dari suatu populasi, terdapat bermacam-macam cara yang dikemukakan para ahli, antara lain pendapat slovin yang dirumuskan sebagai berikut (Husein Umar, 2001):

$$
\mathrm{n}=\frac{N}{1+\mathrm{N}^{2}}
$$

dimana:

$$
\begin{aligned}
& \mathrm{n}= \text { ukuran sampel } \\
& \mathrm{N}= \text { Ukuran populasi } \\
& \mathrm{e}= \text { persen kelonggaran ketidak telitian } \\
& \text { karena kesalahan pengambilan } \\
& \text { yang masih dapat ditolerir atau } \\
& \text { diinginkan, dalam penelitian ini } \\
& \text { digunakan } 10 \text { persen } \\
& \mathrm{n}=\frac{144}{1+144 \quad, 1^{2}}=59
\end{aligned}
$$

Jadi ukuran sampel yang reprensentatif dalam penelitian ini dalah sekurang - kurangnya 59. Dari perhitungan dengan diketahui jumlah populasi 144 orang, didapat hasil sebesar 59 orang sebagai sampel. Sampel diambil secara proporsional sampling yaitu pengambilan sampel dengan memberikan proporsi menurut jumlah populasi di masing-masing kecamatan. Adapun penarikan sampel dapat dilihat pada tabel berikut ini : 
Tabel 3. Distribusi Sampel Berdasarkan Kecamatan di Kota Mataram

\begin{tabular}{|c|c|c|c|}
\hline Kecamatan & Kelompok Sadar wisata & Populasi & Sampel \\
\hline Sekarbela & $\begin{array}{l}\text { Bajang Kano,armanda dan bajang } \\
\text { maju }\end{array}$ & 21 & $(21 / 144 * 59)=9$ \\
\hline Ampenan & $\begin{array}{l}\text { Ampenan Bahari, Ampenan Bahari II, } \\
\text { Banjar Indah, Bintaro Indah }\end{array}$ & 44 & $(44 / 144 * 59)=18$ \\
\hline Cakranegara & $\begin{array}{l}\text { Melati, Gelombok Cinta, Rasa } \\
\text { Sayang }\end{array}$ & 33 & $(33 / 144 * 59)=13$ \\
\hline Mataram & $\begin{array}{l}\text { Pesona Mandiri, Beriuq Maju, Mekar } \\
\text { Sari,kenanga,Mawar merah }\end{array}$ & 46 & $(46 / 144 * 59)=19$ \\
\hline & Jumlah & 144 & 59 \\
\hline
\end{tabular}

Sumber: Data primer diolah, 2014

\section{Teknik Analisis}

Teknis analisis yang digunakan untuk menjawab tujuan penelitian ini adalah analisis berganda dengan tahap sebagai berikut:

\section{Analisis Regresi linier berganda}

Analisis regresi linier berganda digunakan mengetahui usaha industri kerajinan kecil souvenir terkait dengan faktor - faktor yang mempengaruhi pendapatan anggota kelompok sadar wisata di kota Mataram, (Gujarati, 2003; 202)

$$
\hat{\mathrm{Y}} i=\hat{\beta}_{0}+\hat{\beta}_{1} X_{1}+\hat{\beta}_{2} X_{2}+\hat{\beta}_{3} X_{3}+\mathrm{e}_{i}
$$

Dimana:

$\hat{\mathrm{Y}}_{\mathrm{i}}=$ Pendapatan

Tabel 3. Hasil Estimasi Model

\begin{tabular}{|c|c|c|c|c|}
\hline Variabel & & Koefisien & t-statistik & Prob. \\
\hline$\overline{\mathrm{C}}$ & & 3.844028 & 1.506441 & 0.1377 \\
\hline MS (X1) & & 1.110303 & 11.51790 & 0.0000 \\
\hline MLMS (X2) & & 0.281580 & 4.040666 & 0.0002 \\
\hline LB (X3) & & 1.387565 & 2.556264 & 0.0134 \\
\hline R-squared & 0.861569 & & & \\
\hline Durbin-Watson stat & 1.219601 & & & \\
\hline F-statistic & 114.103 & & & \\
\hline Prob(F-statistic) & 0.000000 & & & \\
\hline
\end{tabular}

Sumber: Data primer diolah, 2017

Keterangan : $\alpha=5 \%$, t-tabel $= \pm 2,00$, F-tabel $=1,41$

$$
\begin{array}{ll}
\hat{\beta}_{0} & =\text { Konstanta atau intercept } \\
\hat{\beta}_{1}, \hat{\beta}_{2}, \hat{\beta}_{3}= & \text { Koefisien Regresi } \\
\mathrm{X}_{1} & =\text { Modal sendiri / MS( Rupiah ) } \\
\mathrm{X}_{2} & =\text { Modal diluar modal sendiri MDMS } \\
& \quad(\text { Rupiah }) \\
\mathrm{X}_{3} & \text { Lama berusaha / LB ( Tahun ) } \\
\mathrm{e}_{i} & =\text { Residual term (variabel }
\end{array}
$$$$
\text { 2. Uji Asumsi Klasik }
$$

Dilakukan pengujian asumsi klasik agar model yang telah dibuat tidak bias dan tidak bermakna. Dengan menggunakan tiga asumsi regresi linier klasik yaitu: uji multikolinearitas,uji heterokedastisitas dan uji autokorelasi. 


\section{Pembahasan}

Berdasarkan tabel 3 diatas hasil estimasi regresi linear berganda dengan diperoleh persamaan sebagai berikut:

$\mathrm{Y}=384402.8+1.110303 \mathrm{X} 1+0.281580 \mathrm{X} 2+$ $1.387565 \times 3$

Hasil estimasi diatas dapat dijelaskan bahwa pengaruh variabel independen yaitu modal sendiri, modal diluar modal sendiri dana lama berusaha terhadap variabel dependen yaitu pendapatan adalah dapat dijelaskan bahwa nilai Konstanta (C) sebesar 3.844028.Nilai tersebut mempunyai makna bahwa apabila semua variabel bebas: modal sendiri $(\mathrm{X} 1)$, modal diluar modal sendiri $\left(\mathrm{X}_{2}\right)$ dan Lama berusaha $\left(\mathrm{X}_{3}\right)$ dianggap konstan atau sama dengan 0 (nol) maka jumlah pendapatan anggota kelompok sadar wisata sebesar pendapatan sebesar 3.844.028. Kemudian untuk nilai Koefisien $\beta_{1}$ : Modal Sendiri (X1) menjelaskan bahwa modal Sendiri berpengaruh positif dan signifikan terhadap pendapatan anggota kelompok sadar wisata dalam industri kecil kerajinan souvenir di Kota Mataram. Hal ini ditunjukkan oleh koefisien regresi modal sendiri yaitu sebesar 1.110303 Artinya setiap kenaikan modal sendiri sebesar Rp 1,- maka akan meningkatkan pendapatan sebesar Rp 1.110.

Dari persamaan regresi diatas juga dapat dijelaskan bahwa nilai Koefisien $\beta_{2}$ : Modal bantuan (X2), menjelaskan bahwa Modal bantuan memiliki hubungan positif namun tidak signifikan terhadap pendapatan anggota kelompok sadar wisata dalam industri kecil kerajinan souvenir di Kota Mataram dengan koefisien regresi sebesar 0.281580 dimana artinya setiap peningkatan modal diluar modal sendiri sebesar Rp1 maka akan mengakibatkan kenaikan pendapatan sebesar Rp. $0.281 \mathrm{Hal}$ ini disebabkan oleh dua hal yaitu ;

1. Modal diluar modal sendiri yang terdapat pada anggota responden didapatkan berupa bantuan modal dari pihak pemerintah daerah dan bantuan pinjaman dari pihak perbankan/non perbankan. Dimana pinjaman dari pihak perbankan dan non perbankan memiliki bunga yang relatif masih dijangkau oleh peminjam sehingga akan berdampak pada pendapatan yang diperoleh ditambah lagi dengan jumlah permintaan yang masih rendah dari target penjualan.
2. Modal diluar modal sendiri berupa modal bantuan dari pemerintah yang didapatkan oleh responden masih rendah dan modal yang didapatkan masih rendah dari harapan. Hal ini disebabkan oleh pemberian pinjaman ditinjau dari banyak faktor seperti dari izin usaha,lama usaha yang dijalankan, dan surat - surat penunjang lainnya yang memiliki hubungan.

Kemudian yang terakhir untuk nilai Koefisien $\beta_{3}$ : Lama berusaha (X3) dapat dijelaskan bahwa Variabel lama berusaha (X3) mempunyai hubungan positif dan signifikan terhadap pendapatan anggota kelompok sadar wisata dalam industri kecil kerajinan souvenir di Kota Mataram, dengan nilai koefisien regresi sebesar 1387565, artinya apabila variabel lama berusaha naik 1 tahun atau 12 bulan maka jumlah pendapatan anggota kelompok sadar wisata di Kota Mataram akan meningkat sebesar Rp 138.7565.

Berdasarkan tabel 3 juga dapat diperoleh Koefisien Determinasi (R-square) sebesar 86.0\%. Hal ini menunjukkan bahwa secara keseluruhan variasi yang terjadi pada variabel independen (modal sendiri, modal diluar modal sendiri, dan lama berusaha ) dapat menjelaskan variabel dependen (pendapatan anggota kelompok sadar wisata dalam menjalani usaha industri kecil kerajinan souvenir di Kota Mataram) sebesar 86,0\% persen sedangkan sisanya sebesar 14 persen dijelaskan oleh variabel lain yang tidak disertakan dalam model estimasi, misalnya pemasaran atau promosi hasil kerajinan anggota kelompok sadar wisata. Seperti yang telah diketahui bahwa pada umumnya biaya pemasaran atau promosi yang terlalu tinggi lebih rentan terhadap beberapa resiko pengurangan hasil pendapatan yang diperoleh karena bersifat spekulasi. Selain itu pemasaran atau promosi juga jarang dilakukan untuk menekan biaya. Hanya beberapa orang yang melakukan pemasaran atau promosi atau tidak merata. Para anggota mencoba untuk ikut terlibat terhadap peran pemerintah daerah untuk membantu memasarkan dan atau mempromosikan beberapa hasil industri kecil kerajinan souvenir. 


\section{Uji Multikolenearitas}

Tabel 4. Hasil uji multikolinieritas setiap koefisien variabel

\begin{tabular}{lccc}
\hline & $\begin{array}{c}\text { Modal } \\
\text { sendiri }\end{array}$ & $\begin{array}{c}\text { Modal diluar } \\
\text { modal sendiri }\end{array}$ & Lama berusaha \\
\hline Modal sendiri & 1.000000 & 0.498164 & 0.448952 \\
$\begin{array}{l}\text { Modal diluar } \\
\text { modal sendiri }\end{array}$ & 0.498164 & 1.000000 & 0.414401 \\
Lama berusaha & 0.448952 & 0.414401 & 1.000000 \\
\hline
\end{tabular}

Sumber : Data primer diolah, 2014

Berdasarkan uji multikolineritas menunjukkan bahwa Modal sendiri, Modal diluar modal sendiri dan lama berusaha sebagai variabel independen memiliki nilai koefisien dibawah 0,8 . Hal ini mengindikasikan bahwa tidak ada multikolinaritas antar variabel independen dalam model regresi. Dalam tabel tersebut nilai yang paling tinggi sebesar 0.498164 dan masih dibawah 0,8

\section{Uji Heteroskedastisitas}

Tabel 5: Hasil Uji White Cross Term Heteroskedasticity

\begin{tabular}{lrll}
\hline White Heteroskedasticity Test: & & \\
\hline F-statistic & 0.955093 & Probability & 0.487749 \\
Obs*R-squared & 8.805397 & Probability & 0.455428 \\
\hline
\end{tabular}

Sumber : Data Primer diolah

Berdasarkan Tabel Hasil Uji White Cross Term tersebut karena nilai Prob. Chi-Square(8) yaitu $0,4554(45,54)$ lebih besar dari tingkat signifikansi $\alpha=0,05$. Hal ini menunjukkan bahwa dalam model empiris pada faktor-faktor yang mempengaruhi pendapatan anggota kelompok sadar wisata dalam menjalani usaha industri kecil kerajinan souvenir di Kota Mataram tidak terdapat masalah heteroskedastisitas.

\section{Uji Autokorelasi}

Tabel: Hasil Uji Autokorelasi

\begin{tabular}{lccc}
\hline R-squared & 0.861569 & F-statistic & 114.1036 \\
Durbin-Watson stat & 1.219601 & Prob(F-statistic) & 0.000000
\end{tabular}

Sumber : Data primer diolah, 2014

Dari data yang diolah, maka didapatkan hasil uji autokorelasi dengan nilai Durbin Watson sebesar 1.219 ini berarti bahwa angka Durbin Watson berkisar antara -2 sampai +2 dan hal tersebut menandakan bahwa koefisien regresi bebas dari gangguan autokorelasi.Dari hasil pengolahan data diperoleh bahwa nilai dari Durbin Watson pada model adalah sebesar 1.015 (Lihat lampiran 8). Dengan begitu jadi dapat disimpulkan bahwa tidak ada autokerelasi antar variabel independen dalam model regresi.

\section{Kesimpulan}

Berdasarkan pada hasil penelitian dan pembahasan yang telah diuraikan sebelumnya, maka dapat ditarik beberapa kesimpulan yaitu:

1. Variabel Modal sendiri (X1) dinyatakan signifikan dan berpengaruh positif terhadap pendapatan anggota kelompok sadar wisata dalam di usaha industri kecil kerajinan souvenir di Kota Mataram.

2. Variabel Modal diluar modal sendiri (X2) berpengaruh signifikan terhadap pendapatan anggota kelompok sadar wisata di usaha industri kecil kerajinan souvenir di Kota Mataram.

3. Variabel Lama berusaha (X3) berpengaruh secara signifikan terhadap pendapatan anggota kelompok sadar wisata dalam melakukan usaha industri kecil kerajinan souvenir di Kota Mataram dan hal ini sesuai dengan hipotesa awal

\section{Saran}

1. Tingkat modal diluar modal sendiri yang di dapatkan oleh para anggota kelompok sadar wisata rata - rata masih rendah sehingga menyebabkan bervariasinya pendapatan mereka peroleh untuk meningkatkan pendapatan. Untuk itu maka langkah yang dapat dilakukan untuk menangani masalah ini yaitu dengan menyediakan bantuan tambahan atau modal bantuan oleh pemerintah daerah sehingga diharapkan dapat merangsang usaha yang digeluti oleh para anggota kelompok wisata dalam menciptakan produk unggulan disektor industri kecil kerajianan souvenir 
2. Berjalannya rentan waktu berusaha diharapkan responden atau pengerajin dapat meningkatkan inovasi - inovasi peluang usaha seperti membuat kreasi baru dalam menciptakan produk souvenir yang sesusai dengan permintaan konsumen, kemudian dengan rentang waktu usaha yang berjalan diharapkan juga responden dapat menambah pengalaman dalam menjalani usahanya sehingga dengan mudah membaca situasi pasar.

3. Perlunya dilakukan Pembinaan berkelanjutan oleh Pemerintah daerah terhadap usaha industri kecil khususnya kelompok anggota sadar wisata, sehingga ketrampilan yang dimiliki oleh anggota kelompok sadar wisata dapat dikebangkan lebih produktif . Dengan demikian diharapkan dapat mengahasilkan produk kerajinan yang berdaya saing tinggi.

4. Perlunya dilakukan promosi hasil kerajinan souvenir baik di dalam daerah maupun diluar daerah agar mampu bersaing dengan produk luar dan pada akhirnya meningkatkan pendapatan.

\section{Daftar Pustaka}

Anonim,2003 Proposal Workshop Wisata Petulang dan Ekoturisme

Ali Fauzi ( 2013 ).Analisis faktor - faktor yang mempengaruhi pendapatan pengusaha kasur di desa ngumpul kecamatan jogoroto kabupaten jombang.Sekolah Tinggi Keguruan dan Ilmu Pendidikan Persatuan Guru Republik Indonesia Jombang.

Anik sri sulanjari ( 2013 ). Analisis faktor - faktor yang mempengaruhi pendapatan pekerja pada usaha kerajianan genteng di Kabupaten Sukaharjo. Universitas Sebelas Maret Surakarta.

Aris Ananta, 1993, Ciri Demografis Kualitas Penduduk dan Pembangunan Ekonomi,

Arsyad, Lincolin, 1997. Ekonomi Pembangunan. Yogyakarta. STIE YKPN.

Bintarto. 1996. Tenaga Kerja Dalam Pembangunan. Universitas Indonesia. Jakarta : LP3ES.

Boediono. 1996. Ekonomi Makro. Yogyakarta : BPFE-UGM.

Daryanto, A. 2003. Consestable Market Bogasari [bahan kuliah ekonomi industri]. Fakultas Ekonomi dan Manajemen, Institut Pertanian Bogor, Bogor.

Departemen Perdagangan. 2007. Studi Industri

Kreatif 2007. Depdag, 2007.

Dinas Kebudayaan Dan Pariwisata Provinsi Nusa Tenggra Barat

Dumairy. 1996, Perekonomian Indonesia. Jakarta: Erlangga.
Djojohadikusumo, Sumatri,2002. Perkembangan Pemikiran Ekonomi, Jakarta: Yayasan Obor

Firmansyah, M 2008, Ekonometrika:Aplikasi Regresi Linier, pooling Analysis dan Uji Kausalitas. Arga puji press, NTB

Firdausa (2012 ),Pengaruh modal awal, lama usaha dan jam kerja terhadap pedagang kios dipasar bintaro demak

Gujarati,Damodar N, 2000, Basic Econometrics, Four Edition, Mc Graw hill Higher Education, New York.

Hartanto, F.M. (1987). Paradigma Baru Manajemen Indonesia. Bandung : Mizan Media Utama.

Hasibuan, N. 1993. Ekonomi Industri : Persaingan, Monopoli dan Regulasi. LP3S, Jakarta.

Handoko. 2002. Ekonomi Industri. BPFE, Yogyakarta.

Harimurti, Subanar.2001. manajemen usaha kecil, Yogyakarta: Fakultas ekonomi UGM.

Irawan W Suparmoko (1972)," Pengantar Ekonomi Pembangunan”, BPTE- UGM, Yogyakarta.

I Ketut Tejasinarta (2013). Analisis rendah penadapatan petani rumput laut di desa batununggul. Universitas Pendidikan Ganesha Singaraja Indonesia.

Kartasasmita, Ginandjar. 1996. Power dan Empowerment: Sebuah Telaah Mengenai Konsep Pemberdayaan Masyarakat. http:// www.google.com.

Kotler,Philip.1989. Manajemen pemasaran. Jakarta: Erlangga

Martin. Perry.2000. Mengembangkan Usaha Kecil, (Jakarta: Murai Kencana PT Raja Grafindo Persada

Muchdarsyah Sinungan, 1992, Produktivitas apa dan Bagaimana, Bina Aksara, Jakarta.

Mulyaningrum: Indonesia Dalam Perkembangannya, Kini dan Masa Datang, Jakarta: LP3SES, 2005

Nazir, Moh. 1998. Metode Penelitian. Ghalia Indonesia, Jakarta

Pitana.I Gde.2005. Sosiologi Pariwisata. Yogyakarta. Andi

Rianse, Usman. 2008. Metode Penelitian Sosial dan Ekonomi: Teori Aplikasi. Alfabeta, Bandung.

Simanjuntak, P. 1998. Pengantar Ekonomi Sumber Daya Manusia. Jakarta : LPFE UI.

1990. Pasar Tenaga Kerja. Jakarta : Gramedia Pustaka Utama.

Sudarsono dkk, 1988, Ekonomi Sumber Daya Manusia, Karunia Jakarta, Universitas Terbuka Jakarta.

Sudarman, A. 1990. Teori Ekonomi Mikro. Yogyakarta : BPFE UGM. 
Sumodiningrat,Gunawan. 1999. Pemberdayaan Masyarakat dan JPS. Gramedia. Jakarta

Sumardi, M dan Hans DE. 1995. Sumber Pendapatan Kebutuhan Pokok dan Perilaku Menyimpang. Jakarta : Rajawali.

Sukirno, Sadono: Ekonomi Pembangunan, Medan: Borta Gorat, 2000.

Suroto. 1992. Strategi Pembangunan dan Perencanaan Kesempatan Kerja. Yogyakarta : Gajah Mada University Press.

Timang Setyorini, Kebijakan pariwisata dalam rangka meningkatkan pendapatan ekonomi masyarakat kabupaten

Semarang.Tesis.Universitas

Diponegoro.Semarang, 2004. Tesis
Todaro. 2014. Perkembangan Ekonomi, Edisi Kelima. Jakarta: Bumi Aksara.

Tjiptoherijanto, Priyono. "Situasi Angkatan Kerja dan Lapangan Kerja Sejak Sensus 1971". Analisis CSIS Voi. 3,1989.

Widarjono, Agus. 2005, Ekonomertika: Teori dan aplikasi untuk Ekonomi dan Bisnis, Edisi pertama Ekonisia Fakultas Ekonomi UII, Yogyakarta.

Wijayanti. 2009 Peluang di Bidang Pariwisata. Mutiara Sumber Widya. Jakarta.

Yuliana ( 2006 ). Peranan industri kecil dalam meningkatkan pendapatan masyarakat kasus pada industry kerajinan Batik Kayu di Dusun Krebet, Sendangsari, Pajangan,Bantul. Universitas Sanata Dharma Yogyakarta. Tesis.2006 